\title{
Identification of the features of the regions that are most preferable for the use of precision farming technologies in agricultural production
}

\author{
A.S. Gusev ${ }^{1, *}$, E.A. Skvortsov ${ }^{2}$, and N.V. Vashukevich ${ }^{1}$ \\ ${ }^{1}$ Ural State Agrarian University, Department of Land Management, 620075 Russia, Ekaterinburg, \\ Russia \\ ${ }^{2}$ Ural State Economic University Ekaterinburg, Department of Competition Law and Antimonopoly \\ Regulation, 620219 Ekaterinburg, Russia,
}

\begin{abstract}
As the main hypothesis, it is suggested that the existing unevenness in the number of precision farming elements used in agriculture in the subjects of the Russian Federation is related to regional characteristics and specific features of the agricultural sector of the regional economy. The purpose of the study is to identify the geographical features of the regions that are most preferable for the use of precision farming technology in agricultural production. Mathematical modeling uses data from 20 subjects of the Russian Federation on the dynamics of the introduction and use of precision farming elements and the characteristics of these regions for 14 different indicators that can in one way or another affect the introduction of these technologies. Multiple correlation was obtained using 5 characteristics of regions (the correlation coefficient was $r=0.89 \pm 0.1$ ). At the same time, two indicators (the change in the level of registered unemployment and the amount of subsidies per 1 ha of agricultural land) were inversely dependent on the result of the introduction of precision farming elements. The selected indicators determined the intensity of introduction of precision farming elements in the regions by almost $80 \%$ (the coefficient of determination was $\mathrm{D}=0.798$ ). The identification of these features and the construction of an appropriate model allows to predict the most preferred regions for the use of precision farming elements in agricultural production based on the generalization of existing experience.
\end{abstract}

\section{Introduction}

For the first time, precision farming elements that require GPS to determine the position to which any measured field parameter should be linked began to appear in the late 1980s in the United States and in Australia. A certain contribution to the problem of precision farming technologies was made by both foreign [1] and domestic scientists [2]. One of the first researchers on the application of precision farming elements was the American

*Corresponding author: alexey.anser@gmail.com 
scientist Robert, P. C. According to his conclusions, specific characteristics of the soil condition can significantly expand the tools for production management. These technologies can increase the efficiency of management procedures, increase the profitability of agricultural production and reduce the polluting impact on the environment. According to the conclusions of a number of foreign scientists (Pallottino, F; Biocca, M; Nardi, P; Figorilli, S; Menesatti, P; Costa, C), precision farming elements are a management concept that is based on observations, measurements, and responses to variability in crop cultivation [3]. A number of Russian scientists, primarily L.V. Berezin, L.O. Karpachevsky note that the elements of precision farming are tools for managing crop yields using the intra-field variability of the plant habitat [4].

\section{Materials and methods}

In the Concept of "Scientific and technological development of digital agriculture "Digital Agriculture", developed under the leadership of the Ministry of Agriculture of the Russian Federation by such authoritative organizations as the Russian Academy of Sciences, Moscow State University n.a. M.V. Lomonosov, SRI Higher School of Economics, etc. there is a low level for agricultural organizations using precision farming technologies. It is stated that the share of agricultural enterprises using the Internet of things, precision farming, digital herds and smart greenhouses combined at the end of 2018 is less than $1 \%$. At the same time, the target indicators indicate an ambitious goal to increase this indicator 20 times by 2021, and 60 times by 2024 .

An important factor in the introduction of innovations and in particular elements of precision agriculture is, in our opinion, "the territorial location of economic entities. There is an assumption that the latest technologies should reduce the impact of the geographical location of business entities on the results of their economic activity [5], but regions located closer to large cities are becoming leaders in economic development" $[6,7]$. Geographical features of regions continue to have a significant impact on the ability of economic entities to introduce innovations [8].

As the main hypothesis, it is suggested that the existing unevenness in the number of precision farming elements used in agriculture in the subjects of the Russian Federation is related to regional characteristics and specific features of the agricultural sector of the regional economy. This makes it necessary to search for new universal patterns related to regional features that will improve the efficiency of the process of implementation of precision farming elements. The efficiency of the process of implementation of precision farming elements can be improved if regional characteristics are taken into account, including the rate of agricultural production, the acreage of agricultural crops, and the volume of gross agricultural output in the regions.

The purpose of the study is to identify the geographical features of the regions that are most preferable for the use of precision farming technology in agricultural production.

Research tasks:

1. To specify the number of elements of precision farming technologies and systematize indicators of the state of the organizational and economic potential of the regions using them.

2. To calculate the correlation of relative indicators of various characteristics of regions and the number of precision farming elements used.

3. To build a mathematical model of the intensity of precision farming elements implementation in the regions.

4. To create a territorial model for precision farming elements implemention using the mapping method. 
Diagnostics of the state and subsequent conclusions regarding the elasticity of the precision farming technologies implementation are possible based on the territorial model of these technologies implementation. At the first stage of the multi-factor study, indicators of the state of the organizational and economic potential of the regions will be systematized. These include the following: population density, average monthly nominal accrued wages, share of the working-age population, index of agricultural production in comparable prices, changes in the level of registered unemployment, natural and migration growth (decline) of the population, access to communication services (including broadband Internet), level of state support for the agricultural sector. The number and composition of indicators of the organizational and economic potential of rural areas can be adjusted. At the second and third stages, relative indicators were calculated and territories were ranked depending on the level of precision farming elements implementation. At the fourth stage of the research, a territorial model of introducing precision farming elements is created using the mapping method.

\section{Results and Discussion}

In order to clarify the implementation of precision farming elements, relevant requests were made to the regional ministries of agriculture and agro-industrial complex. The information obtained allows to get official confirmation of data on the use of these technologies in specific regions. A total of 85 official requests were made and 37 responses were received. In this regard, when calculating the correlation indicators between the values of regional development and the number of precision farming elements, we consider only those values that were provided by the regional ministries of agriculture and agro-industrial complex. In some cases, there is a significant discrepancy between these data and the information obtained by other researchers [9].

According to the information received from the regional offices of the ministry of agriculture and agro-industrial complex, the following groups of regions can be distinguished by the intensity of precision farming elements introduction. The first group should include regions with a high level of precision farming elements implementation. These include Amur region (2870 elements of precision agriculture), the Republic of Bashkortostan (2701), Tyumen region (1963), Oryol region (1700), the Udmurtian Republic (1052), Yaroslavl region (665), the Republic of Mari El (633), Kaluga region (582), Omsk region (549) and Sverdlovsk region (538). The second group should include regions with an average level of precision farming elements implementation. These regions include the Orenburg region (88 elements of precision agriculture), Pskov region (129), Arkhangelsk region (224), Leningrad region (74), the Karachay-Cherkess Republic (95), and the Republic of Altai (37). The third group should include regions with a low level of precision farming elements implementation. These regions include the Khabarovsk Territory (48 elements of precision agriculture), Irkutsk region (34), Jewish Autonomous region (22), Kemerovo region (13), Krasnodar Territory (11), and the Republic of Adygea (9). There is a significant discrepancy in the dynamics of the implementation of precision farming elements in the Krasnodar Territory, and therefore data for this region are excluded from further analysis [9]. 


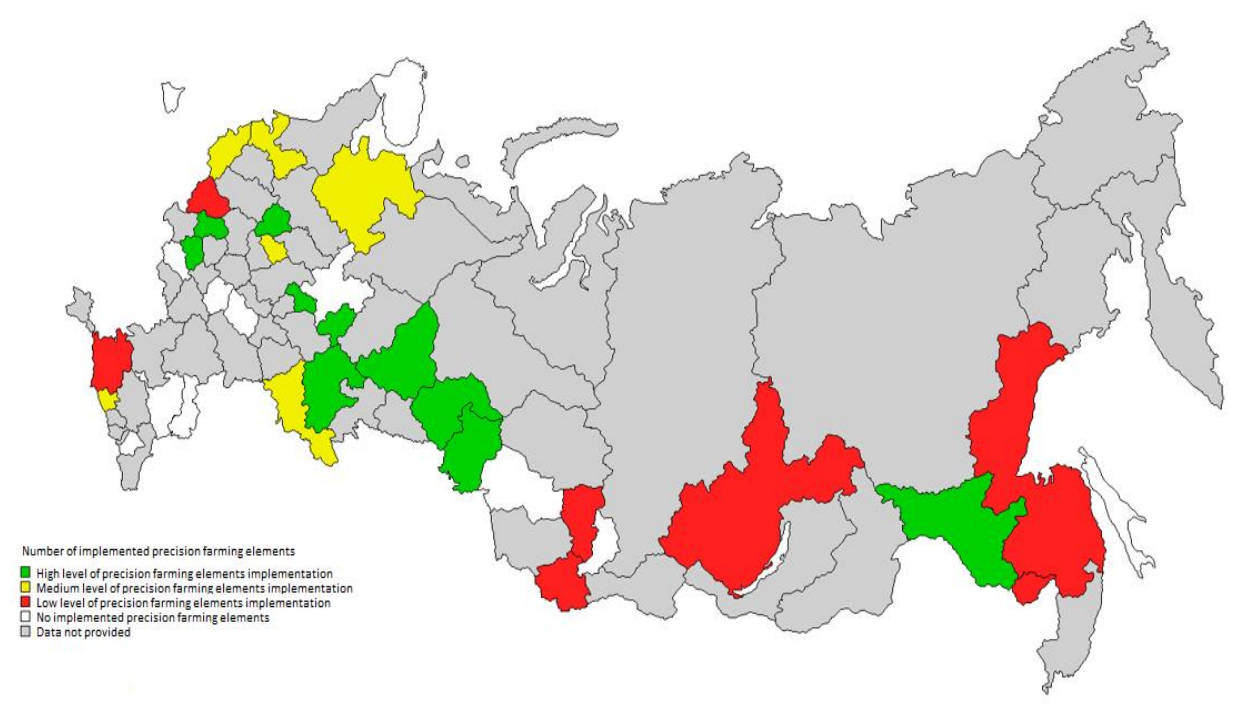

Fig.1. Territorial model of precision farming technologies implementation.

When mathematically modeling the use of precision farming elements, we collected data from 20 Subjects of the Russian Federation on 14 different indicators that can influence the implementation of precision farming elements in the regions to some extent. Mathematical data processing revealed a different correlation between the number of introduced precision farming elements and the estimated indicators (table 1). When compiling mathematical modeling, we selected indicators that have a significant correlation with the number of introduced elements of precision agriculture $(|r|>0)$; there were 5 such indicators: level of registered unemployment, index of agricultural production, acreage of agricultural crops, volume of gross agricultural output, subsidies for agricultural land.

Table 1. Results of correlation of various characteristics of regions and the number of applied precision farming technologies*

\begin{tabular}{|l|c|c|c|}
\hline \multicolumn{1}{|c|}{ Indicator } & $\begin{array}{c}\text { Pair correlation } \\
\text { coefficient }\end{array}$ & $\begin{array}{c}\text { Use in } \\
\text { mathematical } \\
\text { model }\end{array}$ & Factors \\
\hline 1. Share of people employed in agriculture & -0.060 & no & - \\
\hline $\begin{array}{l}\text { 2. Changes in the registered unemployment } \\
\text { rate }\end{array}$ & -0.341 & yes & $\mathrm{X}_{1}$ \\
\hline 3. Labor productivity & 0.199 & no & - \\
\hline $\begin{array}{l}\text { 4. Index of agricultural production in } \\
\text { comparable prices }\end{array}$ & 0.52 & yes & $\mathrm{X}_{2}$ \\
\hline $\begin{array}{l}\text { 5. The share of agriculture in gross value } \\
\text { added }\end{array}$ & -0.123 & no & - \\
\hline 6. Organizations using Internet & -0.11 & no & - \\
\hline $\begin{array}{l}\text { 7. Organizations that used broadband Internet } \\
\text { access }\end{array}$ & -0.19 & no & - \\
\hline 8. Share of crop production in the structure & 0.21 & no & - \\
\hline 9. Sown area of agricultural crops & 0.82 & yes & $\mathrm{X}_{3}$ \\
\hline 10. Yield of grain and leguminous crops & -0.09 & no & - \\
\hline 11. Profitability of crop production & 0.18 & no & - \\
\hline 12. Volume of gross output of agriculture & 0.75 & yes & $\mathrm{X}_{4}$ \\
\hline
\end{tabular}




\begin{tabular}{|l|c|c|c|}
\hline 13. Subsidies for 1 ha of agricultural land & -0.45 & yes & $\mathrm{X}_{5}$ \\
\hline 14. Average monthly salary per employee & 0.22 & no & - \\
\hline
\end{tabular}

Each of the indicators included in the mathematical model is assigned its own designation $\left(\mathrm{X}_{1} \ldots \mathrm{X}_{5}\right)$. The matrix of paired correlation coefficients is presented in table 2 . When determining the multiple correlation, it was found that the correlation coefficient was $\mathrm{r}=0.89 \pm 0.12$, while two indicators had an inverse relationship with the result: the change in the level of registered unemployment and the amount of subsidies per 1 ha of agricultural land. The selected indicators determined the intensity of introduction of precision farming elements in the regions by almost $80 \%$ (the coefficient of determination was $\mathrm{D}=0.798$ ). The matrix of correlation coefficients of the mathematical model is presented in table 2 .

Table 2. Matrix of correlation coefficients of mathematical model

\begin{tabular}{|l|c|c|}
\hline Mathematical model factor & Designation & Correlation coefficient \\
\hline Changes in the registered unemployment rate & $\mathrm{X}_{1}$ & -0.34 \\
\hline $\begin{array}{l}\text { Index of agricultural production in } \\
\text { comparable prices }\end{array}$ & $\mathrm{X}_{2}$ & 0.52 \\
\hline Sown area of agricultural crops & $\mathrm{X}_{3}$ & 0.82 \\
\hline Volume of gross output of agriculture & $\mathrm{X}_{4}$ & 0.75 \\
\hline Subsidies for 1 ha of agricultural land & $\mathrm{X}_{5}$ & -0.45 \\
\hline Multiple correlation & - & $0.89 \pm 0.12$ \\
\hline
\end{tabular}

Based on the results obtained, a regression equation of the following type is compiled:

$$
\mathrm{Y}=-4976.10-58.61 * \mathrm{X}_{1}+50.30 * \mathrm{X}_{2}+1.12 * \mathrm{X}_{3}-0.0024 * \mathrm{X}_{4}+31.75 * \mathrm{X}_{5}
$$

The identification of these features and the construction of an appropriate model allows to predict the most preferred regions for the use of precision farming technologies in agricultural production based on the generalization of existing experience. First of all, it is possible to predict the introduction of precision farming elements in regions with large areas of crops. These are the regions of the Southern Federal district, including the Rostov region (3,304 thousand hectares of grain crops), Volgograd region (2148 thousand hectares of grain crops), the Krasnodar Territory (1851 thousand hectares of grain crops). In the North Caucasus Federal district, this is the Stavropol Territory (2263 thousand hectares of grain crops). In the Volga Federal district - the Republic of Bashkortostan (1753 thousand hectares of grain crops), the Republic of Tatarstan (1429 thousand hectares of grain crops), Nizhny Novgorod region - 2682, Saratov region (2303 thousand hectares of grain crops). In the Ural Federal district, the regions where it is most appropriate to apply precision farming technologies in accordance with the constructed model should include the Kurgan region (1040 thousand hectares of grain crops) and the Chelyabinsk region (1389 thousand hectares of grain crops). In the Siberian Federal district, these regions include the Altai Krai $(3,217$ thousand hectares of grain crops), the Omsk region (1,950 thousand hectares of grain crops), and the Novosibirsk region (1,400 thousand ha of grain crops).

\section{Conclusion}

Thus, a mathematical model of the intensity of precision farming elements implementation in the regions is proposed, which will allow predicting the further development of digitalization of domestic agriculture.

It should be noted that there is a negative correlation between the implementation of precision farming elements and changes in the registered unemployment level. This may 
indicate that elements of precision farming are mainly being introduced in regions with low levels of registered unemployment. It can also be assumed that the main elements of precision agriculture are implemented in regions with developed industrial production, which is the center of labor force attraction. This, in turn, encourages farmers to introduce labor-saving technologies in agriculture, including those with precision farming elements.

An important relationship identified is the negative correlation between the implementation of precision farming elements and the amount of subsidies per 1 ha of farmland. This may indirectly indicate that these subsidies are not spent on the acquisition of precision farming elements, but on subsidizing the costs of reclamation, seed acquisition, and other targeted costs. This also allows to conclude that the amount of subsidies for precision farming elements is currently not significant in comparison with other subsidy items.

\section{Acknowledgements}

The study was performed with financial support RFBR within the framework of the research project No. 20-010-00827A "Study of the theoretical aspects of the use of precision farming technologies in agricultural production", as well as the regional offices of the ministry of agriculture and agro-industrial complex for data provided.

\section{References}

1. P.C. Robert, Geoderma, 605, 772 (1993)

2. E.V. Truflyak, Basic elements of the precision farming system (Krasnodar :KubSAU. 2016)

3. F. Pallottino, M. Biocca, P. Nardi, S. Figorilli, P. Menesatti, C. Costa, Precision agriculture, 19(6), 1011-1026 (2018)

4. L.V. Berezin, Innovative technologies in soil science, agrochemistry and ecology (Modern problems and innovations in soil science): learning guide (Publishing house of the FSBEI HPE OmSAU n.a. P.A. Stolypin, 2012)

5. Leonard C. Spatial, Foresight and STI Governance, 10(3), 30-33 (2016) DOI: 10.17323/1995-459X.2016.3.30.33

6. M.J. Enright, Survey on the characterization of regional clusters: Initial results (Hong Kong: University of Hong Kong, 2000)

7. B.T. Asheim, P. Cooke, R. Martin, The rise of the cluster concept in regional analysis and policy, Clusters and regional development: Critical reflections and explorations (London: Routledge, 2006)

8. N. Davidson, O. Mariev, A. Pushkarev, Foresight and STI Governance, 12(3), 62-72 (2018)

9. E.V. Truflyak, Using elements of precision agriculture in Russia (Krasnodar: KubSAU, 2018) 